\title{
Forest restoration in the floodplains of the Amazon estuary subjected to intensive açaí management
}

\author{
Rosileia da Costa Carvalho \\ Lívia de Freitas Navegantes Alves \\ Renan do Vale Carneiro
}

${ }^{I}$ Mestre em Agriculturas Familiares e Desenvolvimento Sustentável, Universidade Federal do Pará, Belém, PA, Brasil.

II Doutora em Agroecossistemas e Professora da Universidade Federal do Pará, Belém, PA, Brasil.

III Mestre em Agriculturas Familiares e Desenvolvimento Sustentável, Universidade Federal do Pará, Belém, PA.

\begin{abstract}
The expansion and intensification of açaí management in floodplain forests of the Amazonian estuary have resulted in changes in floristic composition and in biodiversity losses, causing problems to ecosystems and endangering livelihoods of riverine communities. These transformations have prompted the need for forest restoration. The objective of this study was to identify and analyze forest recovery initiatives carried out in floodplain forests previously subjected to intensive açaí management in the Amazonian estuary. Methods included structured interviews and questionnaires. Results reveled the following restoration types: 1) area enrichment: subtype 1 - high floodplain forest (7.89\%) and subtype 2 - low floodplain forest $(44.75 \%) ; 2$ ) directing natural regeneration of native species $(34.21 \%)$; 3) cultivation of native species $(13.15 \%)$. Results suggest that forest restoration efforts can promote sustainable production of açaí, productive diversity, ecosystem conservation and generate income for riverine families.
\end{abstract}

Keywords: Agriculture; sustainable development; riverine peoples biodiversity.

São Paulo. Vol. 24, 2021

Original Article

DOI: http://dx.doi.org/10.1590/1809-4422asoc20180269r3vu2021L2AO 


\section{Introduction}

Ecosystems of the Amazonian estuary consist of flooded forests that are predominated by açai palms (Euterpe Oleracea Mart.) that grow in dense stands dispersed with among other palms and hardwood species (ALMEIDA; AMARAL; SILVA, 2004; JARDIM; VIEIRA, 2001; REIS; ALMEIDA, 2012). The influence of daily tides, water salinity and richness level, differentiate estuarine floodplain forests (várzeas) from other floodplain forests in Amazon (MORÁN, 1990).

In the lower Tocantins region ("Baixo Tocantins"), particularly in the municipality of Abaetetuba, Pará, Brazil, these areas are characterized as tidal floodplains, which are influenced by daily tidal movements. These areas are located on riverbanks and are intersected by a series of smaller waterways, locally known as furos and igarapés (LIMA; TOURINHO, 1994; LIMA; TOURINHO; COSTA, 2000; REIS, 2008; REIS; ALMEIDA, 2012).

The açai palm (Euterpe oleracea Mart.) is one of the most abundant and commonly occurring plants of the Amazonian estuarine floodplains. It is native to the region and is of great cultural and economic importance. Research shows that açaí can account for up to $25 \%$ of all plant species found in estuarine floodplain forests. Currently, the management of açai is the primary income source for riverine peoples (ribeirinhos) of the Amazonian estuary. (ANDERSON et al., 1985; LOPES; SANTANA, 2005).

The importance of forest preservation also stems from the need to conserve the production of this fruit in the long term, since the current intensive production system has demonstrated problems in terms of its sustainability.

Açaí has always been a traditional Amazonian food, especially in the estuary - without its consumption causing significant impacts on the natural environment. However, it's growing economic importance, as a result of increased local, national and international demand, has led to a decrease in biodiversity levels in estuarine floodplains, and consequently the elimination of certain plant species, even species useful to local peoples, such as miriti (Mauritia flexuosa L) (NOGUEIRA; FIGUEIRÊDO; MÜLLER, 2005).

Acording to Zarin et al. (2001), the reduction of flooded forests in Amazon was partially caused by the expansion of açaí stands in forest management areas, locally called açaizais (referred to in this paper as açaí stands or groves).

The impacts of intensive management of açaí on biodiversity and forest composition in floodplain areas has been widely discussed by Homma et al. (2006), Nogueira (2008), Brondízio (2008), Araújo and Navegantes-Alves (2015). In this way, this study primarily discusses the process of densifying açai stands in floodplain forests through forest thinning practices, which in extreme cases can transform the forested areas into plantation-like vegetation.

Market demand for açaí motivated ribeirinhos to intensely manage açaí stands in forested areas. According to Araújo and Navegantes-Alves (2015) açaí management is characterized by a high level of human intervention and consists of practices like thinning, in which some species are eliminated to prioritize the growth of açai palms. 
Intensive management of açaí has caused forest fragmentation and consequently changed the landscape, such that açai has an outstanding presence in floodplain forests. Hiraoka (1993) calls this transformation process the "açaização" of the landscape because this species stands out visually relative to others.

Evidence of natural resource degradation, especially the destruction of gallery forests, biodiversity loss and sedimentation of rivers, has propted ribeirinhos to mitigate such problems through forest restoration practices. Such practices, however, have not received visibility in Amazon, especially in the estuarine region. As a result, little is known about the dynamics of forest restoration, especially in regard to agroecological processes.

In this study, forest restoration is understood as a process that involves the gradual recovery of native vegetation over time. It includes the re-introduction of various species, including those that comprised the original vegetation, encompassing various life forms. This process thus enables the return, maintenance and balance of the environmental system and its functions (RODRIGUES et al., 2007).

As such, this study aims to identify and analyze experiences in forest restoration carried out by ribeirinhos in floodplain forests of the Amazonian estuary that were previously subjected to intensive açaí management.

\section{Methodology}

\section{Study area}

This study was conducted in the "island region" of the municipality of Abaetetuba, located in the Microregion of Cametá, which includes the municipalities of Cametá, Baião, Igarapé-Miri, Limoeiro do Ajuru, Mocajuba and Oeiras do Pará, which in turn is part of the Mesoregion of Northeast Pará state, Brazil. The municipality covers $1,611 \mathrm{~km}^{2}$ (IBGE, 2010) (Map 1) and includes one of the most productive açai regions in Amazon. This area measures $1610,743 \mathrm{~km}^{2}, 40 \%$ is made up of floodplain zones and is locally referred to as "sitio". The floodplain region of Abaetetuba encompasses 72 islands, including 24 Agro-Extractive Settlement Projects (Projetos de Assentamentos Agroextrativistas - PAE, or PAEs plural) and 7 Quilombola territories. While many denominations exist: caboclo, extractivists, fishers, the local population recognizes itself as ribeirinhos (riverine peoples) and has a strong relationship with the natural environment. 
Map 1 - Location of study area, fluvial islands, Abaetetuba, PA, Brazil.

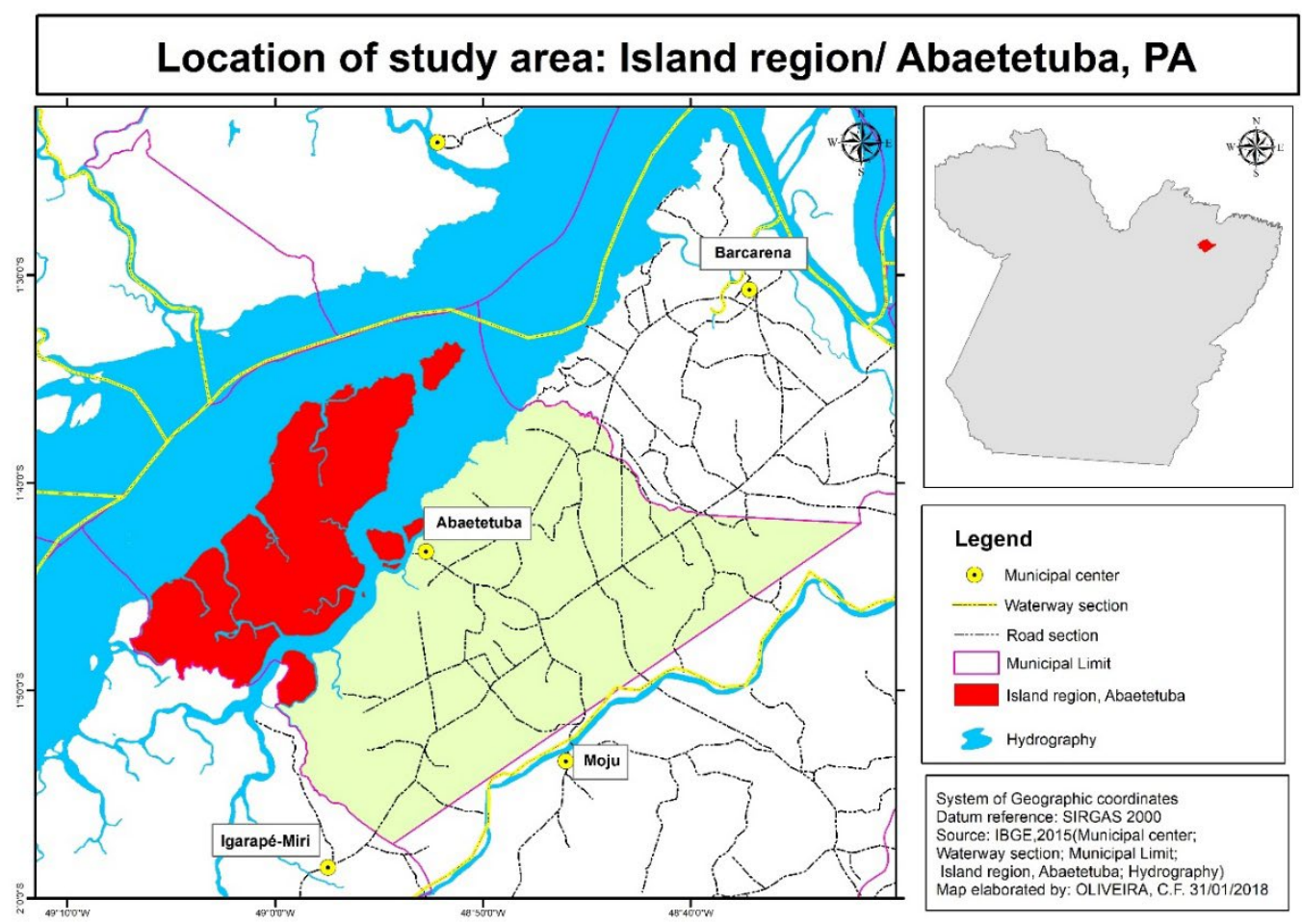

Source: Field research, 2017.

\section{Data collection and treatment}

Fieldwork for this study was carried out from March to May of 2017. First, five historical interviews were conducted, using a flexible script (appendix B). Interviews were conducted with key informants affiliated with institutions linked to family farming and açai production in Abaetetuba. Interviews sought to identify the factors and events that most influenced forest recovery processes in regional floodplain forests.

Historical interviews (MICHELAT, 1987) allowed for the identification of individuals involved in forest restoration activities on the Abaetetuba islands, since these individuals are in continual contact with the key interlocutors of our study. During an interview with the local Agricultural Extension Agency (Empresa de Assistência Técnica e Extensão Rural - EMATER), 3,200 forest recuperation initiatives in the Abaetetuba islands region were identified, which is estimated to correspond to $41.5 \%$ of all ribeirinho families. These data are based on statistics compiled by the National Land Reform Agency (Instituto Nacional da Colonização e Reforma Agrária - INCRA), which was responsible for implementing the land reform projects in the islands beginning in 2008, which organized them into agro-extractivist settlements. 
After identifying research subjects, 38 questionnaires were conducted (ALBU. QUERQUE; LUCENA; CUNHA, 2010) with riverine peoples who engage in forest recovery initiatives in the island region of Abaetetuba. In all, 21 ribeirinho communities were included in this research phase, which allowed for a socioeconomic analysis and the identification of ongoing forest recuperation initiatives in areas previously subjected to intensive açai management. Questionnaires were filled out by the first author during one-on-one interviewees with participants, as recommended by Michelat (1987). It is worth mentioning that the first author is part of the studied universe, belonging to the ribeirinho social group. This social position allowed for a greater understanding of phenomena observed and reported in the field, in addition to providing the work with a strong empirical basis.

Our research resulted in the elaboration of a typology of forest restoration experiences, which revealed three types of initiatives carried out by farmers.

\section{Results and discussion}

\section{Types of forest recuperation in floodplain areas}

Forest recuperation initiatives were categorized into 3 distinct groups. The first includes 2 sub-types, Type 1: Area enrichment (sub-type 1- high floodplain forest and sub-type 2- low floodplain forest); Type 2: Directing the natural regeneration of native species; Type 3: Cultivation of native species.

Type 1 - Area enrichment: it is done by $52.64 \%$ of all interviewees who use cultivation techniques during restoration processes; areas are characterized by high levels of diversification. Recovery areas are enriched with fruit and timber species, using seedlings produced by ribeirinhos themselves. These areas present high diversity (on average 15 species/ha.) and diverse plant compositions in accordance with the ecosystem, as shown in Figure 1. These areas were considered enriched, since they were previously modified by intensive açaí management; or, in other words, suffered from significant human intervention, and as result presented low floristic diversity. In these areas, farmers enriched plots through planting seedlings - introducing new species into targeted forest restoration areas (NBL ENGENHARIA AMBIENTAL; THE NATURE CONSERVANCY, 2013). Area enrichment through cultivation is recommended when the existing vegetation presents low species diversity. In this case, seedlings were planted between açaí palms, in accordance with the cultivation season; according to ribeirinhos, the period of most intense rains, from January to May, is best for planting different species in açaí groves. 
Figure 1 - Composition of forest type 1: area enrichment

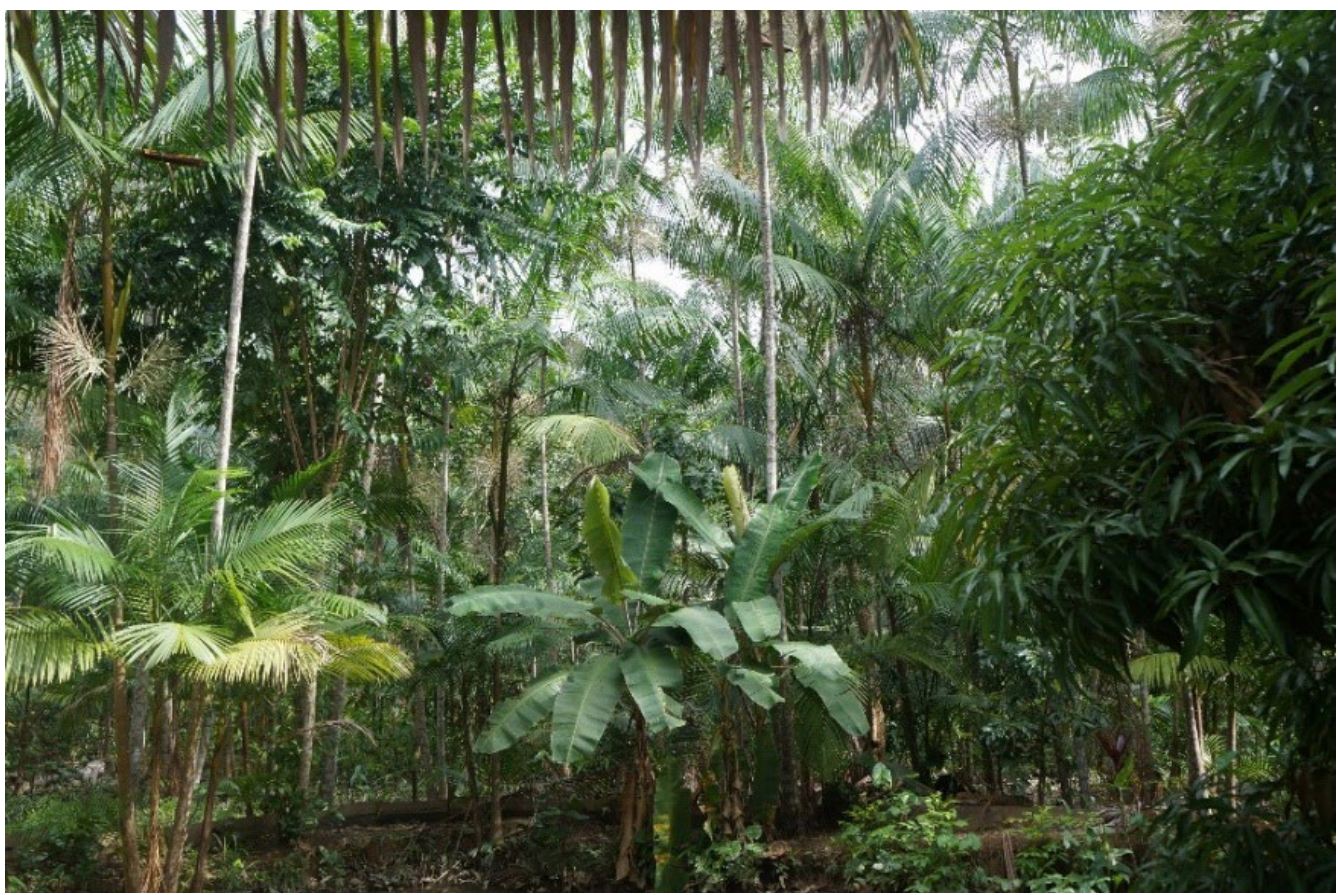

Source: Field research, 2017.

Sub-type 1 - High floodplain forest (7.89\%): The high floodplain ecosystem is a transition area between the upland ("terra firme") forests and the floodplains. Due to its similarity to the upland forest ecosystem, it presents a higher species diversity, as compared to the low floodplain forest. Most of the species that ribeirinhos cited as occurring in this forest type are also found in upland forests in Amazon.

Sub-type 2 - Low floodplain forest (44.75\%): This sub-type presents a distinct ecosystem, resulting from daily flooding, which directly influences the composition of its enriched forests. According to Silva et al. (1992), low floodplain forests present a lower diversity compared to the high floodplains because few species have morphological mechanisms that allow them to withstand daily flooding. In this sub-type, açai palms can be found associated with other fruit and timber species, being either cultivation species or resulting from natural forest regeneration. However, given the limitations of the ecosystem, ribeirinhos do not have the same flexibility of introducing the same range of species as they do in the high floodplain forests.

Type 2 - Directing natural regeneration of native species: this practice is done by $34.21 \%$ of all interviewees. This type of restoration demands little human intervention in its initial phase; and directing natural regeneration is done through species selection. This process in is more complex in the floodplain because ribeirinhos generally do not have the tools or resources to remove undesired species mechanically or chemically, nor 
do they have the means to guarantee that native species, beneficial to açaí stands and ecosystem recovery processes, remain in management areas.

This restoration type favors the growth of natural forests through the recovery of native species. As such, ribeirinhos encourage the development of environments similar to the forests that existed before degradation processes, as shown on Figure 2. The diversity of species (herbaceous, shrubs, vines, and palms) that emerges during natural regeneration processes allows for the consolidation of a restored forest - which is the result of the reestablishment of important ecological processes (NBL ENGENHARIA AMBIENTAL; THE NATURE CONSERVANCY, 2013).

Figure 2 - Composition of type 2 forest: directing the natural generation of native species

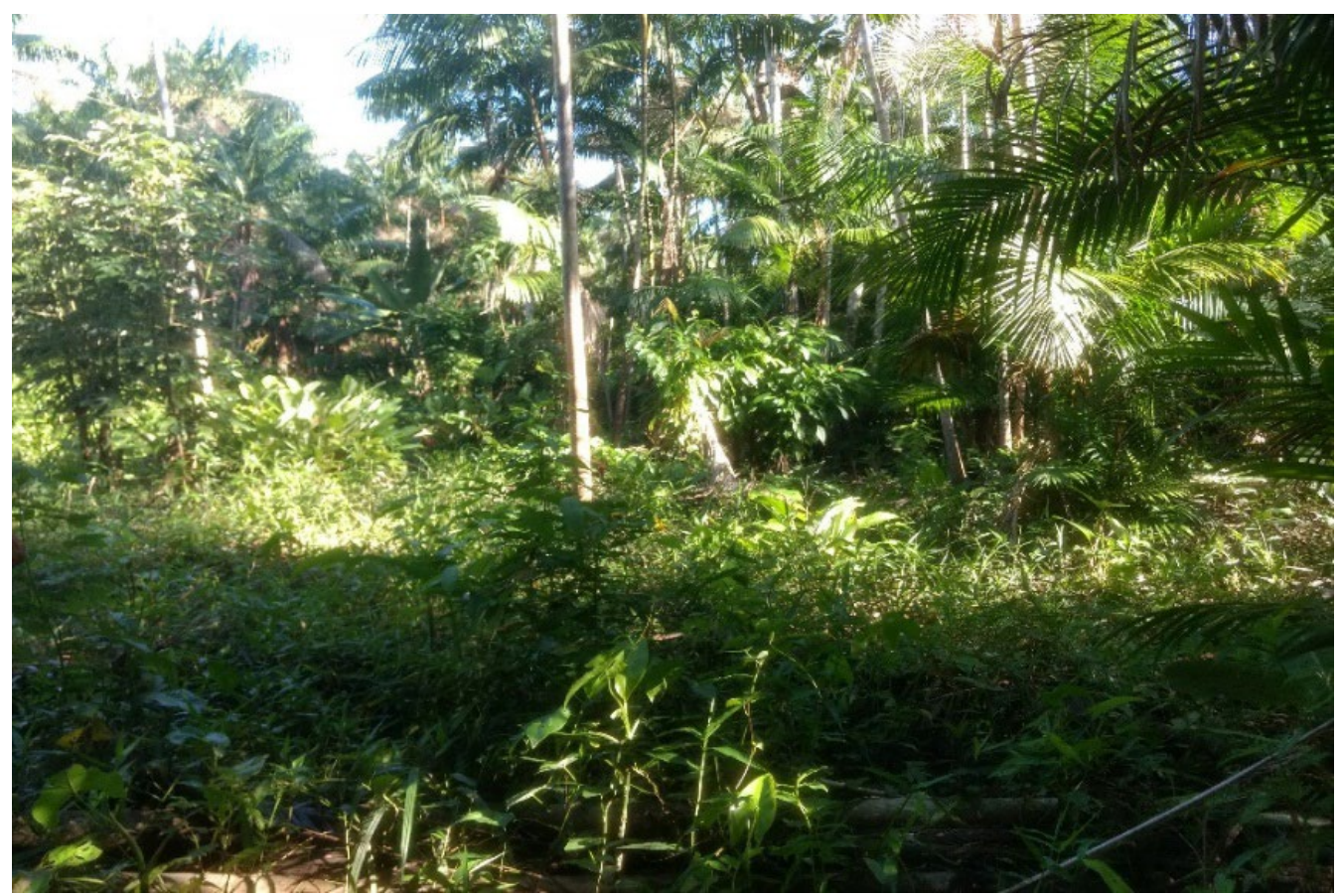

Source: Field research, 2017.

In directing natural forest regeneration, ribeirinhos leave in place species that are beneficial to açaí growth, which include those that provide fertilizer and provide shade; they also preserve timber and other economic species. Species outside of these cited categories that have local symbolic value are also left in place.

Type 3 - Cultivation of native species: this type was cited by $13.15 \%$ of all interviewees and can be characterized as a subtle form of forest restoration. In these areas, açaí palms are still dominant in relation to other trees and present a low floristic diversity, as 
shown on Figure 3. Açai fruit production is favored in these cases; producers who maintain these areas do so primarily for commercial purposes. As such, producers apply more controlled forest restoration techniques, such as measures that both prevent the growth of invasive species and favor the development of shade species.

Figure 3 - Composition of type 3 forest: cultivation of native species

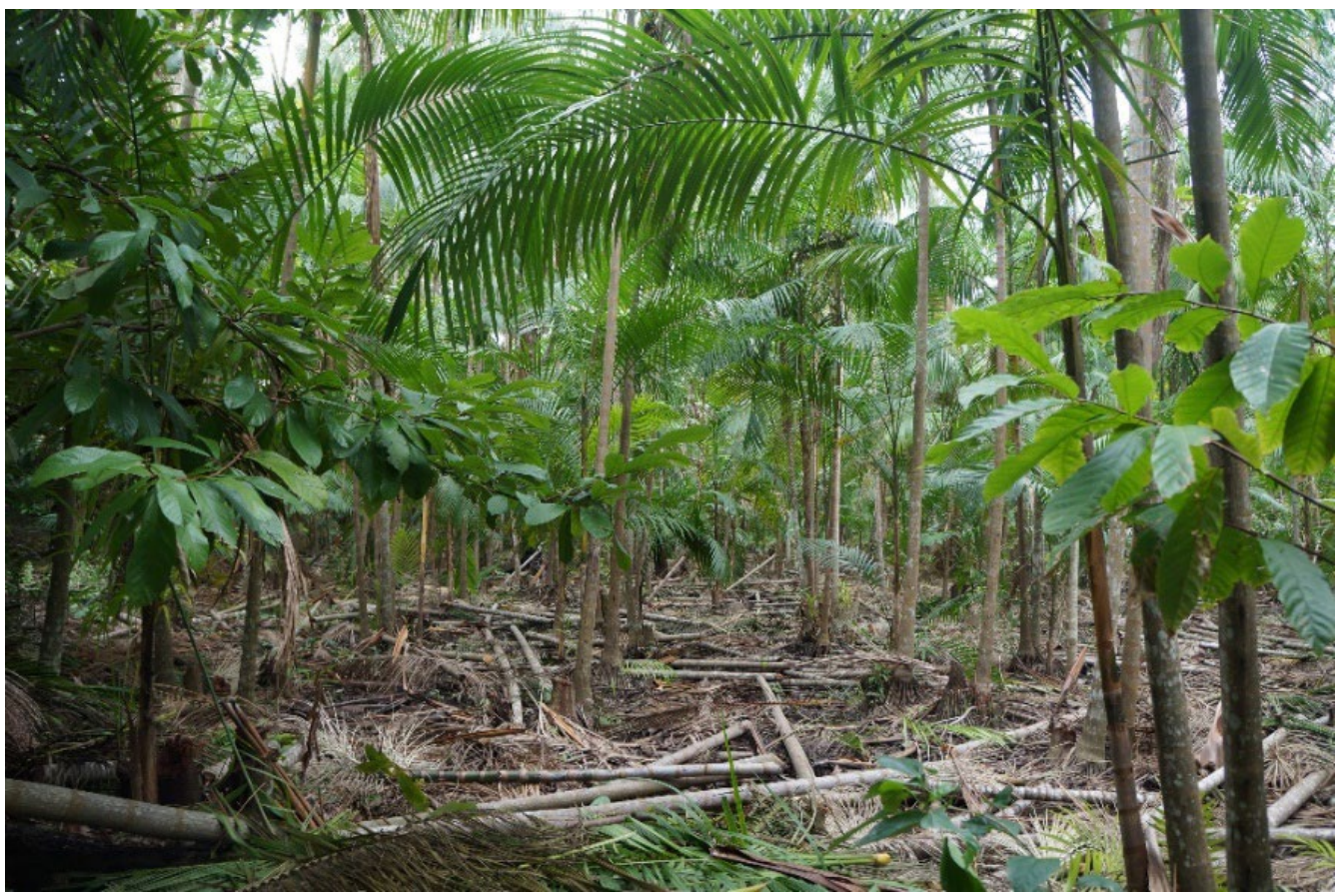

Source: Field research, 2017.

Restoration of açaí groves through cultivation is done by ribeirinhos who believe that introducing too many species will harm açai production. With a high degree of investment, farmers plant a combination of fast-growing and intermediate to late successional species. Tree planting in these cases serves to overcome the low floristic diversity of forests intensely managed to favor the growth of açaí.

Data show that forest restoration practices are adopted by many ribeirinhos and is thus a consolidated process in the region incentivized by the federal government and the local rural extension agency (EMATER-Pará). The latter specifically supports forest recovery initiatives by granting lines of credit to assist smallholders' sustainable management projects.

The emergence of these lines of credit demonstrates a recent change in the conception of açaí management promoted by regional technicians. At the beginning of açaí expansion in the 1990s, extension agents encouraged farmers to expand and densify their açaí groves through intensive management. In the end, however, these techniques, were 
not well evaluated by ribeirinhos who identified problems with açaí fruit production, including premature fruit drop, such that EMATER itself began to promote the diversification of açaí management areas.

\section{Factors that influence the adoption of forest restoration practices}

During our research, ribeirinhos reported several problems related to intensive management of açaí stands. The occurrence of pests and diseases, açaí fruit and leaf dehydration, and even the death of the entire açaizais were among the events that led ribeirinhos to seek restoration techniques.

Environmental concerns led ribeirinhos to seek sustainable alternatives to restore ecosystems and maintain environmental services. Ribeirinhos generally correlate environmental services with maintaining their quality of life and well-being and, subsequently, the long-term productivity of açaí management areas.

Ribeirinhos also identified increasing productive diversity as reason for undertaking forest restoration. Related to this point, $40 \%$ of respondents said they perform forest recovery practices to promote diversity and ensure another income source (from the sale of alternative products) and thus have more autonomy, especially when açaí is not in season.

This process has positive environmental consequences overall and it also works in favor of açaí production. Other species supply nutrients to açaí palms via organic matter accumulation and their presence balances out light infiltration in açaí groves.

Diversification is also a response to the recent drop in the price of acai fruit in Abaetetuba. Even with the spread of forest restoration practices, the area under açaí cultivation has grown throughout the region. With the increased supply of the fruit, the price has fallen, thus generating concern among ribeirinhos over the overall decline of earnings from açai production - something that occurred in past production cycles in the region. These observations were also highlighted by researchers in the region, such as Cialdella and Navegantes-Alves (2014).

Everybody is planting açaí. In a little while we will only have this [fruit], you'll look for a fruit to eat, you won't find one, you'll have to buy it; and even more, with so much açai in the region, the price is falling. I can't earn more than $\mathrm{R} \$ 20,00$ per basket [rasa] during the season; it's difficult and we also have expenses - with the collectors, cleaning of açai stands, and other things. If you don't have another source of income, it won't work out (Mr. André, ribeirinho - 53 years old).

Another group of interviewees affirmed that the problems identified in açai stands were caused by climate change. Indeed, $95 \%$ of interviewees stated that over the last 10 years the climate has become warmer and that this change has caused losses in the production of açai and other products, such as miriti. They attribute climate change to deforestation from logging and livestock production in the uplands of more distant regions. 
Furthermore, according to interviewees, the introduction of other plants in the middle of açai stands through forest restoration practices, makes the environment more robust and able deal with external disturbances. Studies carried out in the municipalities of Abaetetuba and Igarapé Miri showed that when the management of açai stands is intensive, it results in biodiversity losses and soil erosion, and that such management practices have negatively affected açaí fruit quality and yields (NOGUEIRA; FIGUEIRÊDO; MÜLLER, 2005).

The Brazilian Agricultural Research Corporation (Empresa Brasileira de Pesquisa Agropecuária - Embrapa) of Eastern Amazon and EMATER-Pará developed guidelines on best management practices for açaí production in floodplain areas. They recommended that açaí groves be managed in combination with other tree species, accounting for about 30\% of all individuals (FERREIRA, 2013; NOGUEIRA; FIGUEIRÊDO; MÜLLER, 2005). Yet, despite this and Brazilian environmental laws dating back to 1965 (undergoing changes in 2012) that set requirements for conserving native vegetation, the suppression of vegetation has remained intense for decades (BENINI et al., 2016). In the Lower Tocantins region, logging and the expansion of açaí stands were the main factors that contributed to the removal of native plant species in Permanent Preservation Areas (Áreas de Preservação Permanente - APP).

In this study, $95 \%$ of interviewees stated that they consider intensive açaí management practices as predatory and unsustainable. Therefore, efforts to conserve the floodplain forest can be justified by environmental concerns, including the desire to conserve streams, riverbanks and other waterways, as well as the forest which shelters animals. Presenting improved environmental conditions is characterized in the scientific literature as the maintenance of ecosystem services; for ribeirinhos, on the other hand, it is as way to preserve their quality of life and well-being.

In addition, forest restoration can be encouraged by the potential livelihood contributions it offers these rural producers. Schneider (2004) points out that crop diversification not only increases income possibilities, but above all, has the potential to guarantee the economic, social and cultural reproduction of different social groups - insofar as it provides a combination of products, originating from actions, initiatives, choices, and strategies that aim to support families' livelihoods.

The local office of EMATER-Pará in the Lower Tocantins region has registered more than three thousand açaí management projects. These initiatives are aimed at the "rational" management of açaizais and stimulated the diversification of these areas through the introduction of forest species. The projects are part of the National Program for the Strengthening of Family Farming (Programa Nacional de Fortalecimento da Agricultura Familiar - PRONAF), and part of the PRONAF-Forest credit line. In addition, EMATER provides benefits to more than 200 ribeirinho families in the municipality, through its PRONAF A credit line, which, in the study site is directed primarily toward açai production. Although it is a differentiated credit line and extends a relatively lower amount of funds, guidelines regarding the production diversification are the same as those set for PRONAF/Forest. 
Finally, it is important to mention that since many ribeirinhos engage in forest restoration on their own or come to these practices through the influence of Non-governmental organizations (NGOs) and social organizations, without necessarily accessing funding, the number of such initiatives is greater than the EMATER database suggests.

\section{Choosing species for forest restoration in floodplain forests}

The choice of species used in restoration activities in high and low floodplain forests occurs in relation to plant behavior and adaptation to its specific environment. On the other hand, the intense cultural relationship between ribeirinhos and some plant species - which do not always have an economic value - influences this process. Lira and Chaves (2015) affirm that traditional Amazonian communities, of which ribeirinhos are one example, have cultural systems that do not separate humans from nature and a way of seeing the world and a moral order that are products of their cultural heritage. Valuing and respecting trees is one of the most striking characteristics of this culture.

Ribeirinhos have their own flora and fauna classification system, which is part of their extensive cultural heritage (LIRA; CHAVES, 2015). In this study we identified species characterized as "strong" or "weak". Strong species are placed in situation of social prestige, and as Gouveia (2003) argues, prestige motivates practices. For ribeirinhos the forest is also generally embedded with symbolism. "Strong" species are usually the most vigorous, rare and largest trees, such as: pau-mulato (Callycophyllum spruceanum Benth), massaranduba (Pouteria sagotiana (Baill) Eyma, pracuúba (Pentaclethra macroloba (Willd.). Kuntze) and cedro (Cedrela fissilis Vell.).

Species considered "weaker" due to having little commercial value or not being apt for construction purposes, are also known as "white timbers", and in general, are used in extractive practices. The most well-known species are: ucuuba (Virola surinamensis (Rol.) Warb.), murumuru (Astrocaryum murumuru. Mart) and jaranduba (Zygia ampla (Spruce ex Benth.) Pittier). Even though these species are considered "weak" - through these individuals ribeirinhos express their belief system, myths, rites and knowledge that govern their way of life (LIRA; CHAVES, 2015). It is in this context that Morán (1990) states that human-nature relations are mediated by culture.

Forest restoration processes thus occur within the above universe of cultural values. The cultivation, maintenance, and preservation of desired species are guided by knowledge passed down through generations, which are sometimes also accompanied by technical-scientific knowledge. Ribeirinhos usually value the species that were cultivated by their ancestors since they represent the continuity of tradition. Women contribute significantly to this ongoing traditional relationship with nature. Women are protagonists in forest restoration processes and have rescued species nearing extinction in the region - many of which have important medicinal values, such as copaíba (the bark) and jatobá (the root and bark).

Attached to this article (appendix A) is a table that lists 55 useful species found in 21 ribeirinho communities. Multiple uses are listed for each and the plants are distributed over the different types of forest restoration areas. The most commonly occurring species 
in the sites were: açaí (Euterpe oleracea Mart.), andiroba (Carapa guianensis Aubl), ucuúba (Virola surinamensis (Rol. War), miriti (Mauritia flexuosa L.), and pau-mulato. Açaí is the most prominent component in the system since production is meant to meet market demands.

Species used for forest restoration throughout all the different areas are important for economic, medicinal and culinary purposes. They area also crucial for maintaining communities' traditional knowledge, as they motivate actions for conservation and the sustainable use of the areas, in addition to improving the environment.

Species richness in high floodplain areas is positively influenced by the ecosystem, which resembles the uplands. On contrary, fruit species are options for those who aim to recover areas in low floodplain forests. Research shows that ribeirinhos opt for fruit species for different reasons. Salomão, Terezo, and Jardim (2007) and Araújo and NavegantesAlves (2015), point out that floodplain forest species generally have many buttress and deep roots that aim to support tall trees, such as the mututizeiro and the ucuubeira. These traits are considered detrimental to the growth of açaí because they take up too much space - as support roots extend beyond the basal area of individual trees, affecting surrounding açaí palms.

Species present in type 2 areas (directed natural regeneration) were sometimes deliberately cultivated by local peoples. However, we also found diverse plants that regenerate spontaneously and are maintained or favored through management practices when deemed useful to farmers.

In terms of type 3 area, cultivation of native species, we found that producers practiced forest restoration to maintain açaí productivity. As shown on Table 1 (appendix A), few forest species are used in these types of restoration areas because ribeirinhos focus on maintaining species that benefit açaí. Among these species are "facãozeiro", which 98\% of interviewees cited as being extremely important to açaí groves; this species helps retain water in soils. The "ingazeiro" was also highlighted as important. This species has been reported by Araújo and Navegantes-Alves (2015) in their work with ribeirinhos in Igarapé-Miri, Pará. The authors reported that both the ingazeiro and "machãozeiro" and are considered beneficial to management areas because they shed many leaves that decompose over time and generate natural fertilizer for açaí palms.

Thus, restoration through planting native species occurs as described by Nair (1993), who states that the planting or maintenance of trees is done for various reasons. In general, there is a focus on economic interests, but planting or protecting certain species are also motivated by ecological interests - since with management ribeirinhos also aim to preserve riparian vegetation lost with intensive management practices.

During our study, we observed that many ribeirinhos concern themselves with conserving biodiversity while also maintaining açaí productivity. Therefore, it is important to prioritize species that meet not only farmers' immediate needs but are also suited to their projected production system (ALMEIDA; AMARAL; SILVA, 2004; HUXLEY, 1999).

Ribeirinhos' initiatives to restore degraded areas promote the resumption of traditional knowledge use, which was at risk of being lost when routine practices were simpli- 
fied. Documented initiatives allow participants to play an active role in the processes of selecting species for reforestation of degraded areas (FRANKE; LUNZ; AMARAL, 2000; GARRAFIEL; NOBRE; DAIN, 1999; MONTES; WEBER, 1997).

Making the most of resources available on ribeirinhos' landholdings, species selection evokes ribeirinhos' implicit knowledge - one that is constantly evolving, corroborating Lima and Andrade (2010) who state that ribeirinhos are always learning. The above authors argue that ribeirinhos are people who learn by doing, and that there is no regulated or specific guide for what to do in the forest, since ribeirinhos acts by intuition and are guided by place-based know-how constructed through his/her daily practice.

Species cultivated or maintained in restoration areas have various potential uses. They are used as food, to build houses or make handicrafts and other utensils used in daily life. Ribeirinhos know all these uses, the best time to plant, species' management needs and other potential uses. Thus, ribeirinhos' extensive knowledge differentiates this group from other traditional communities of upland areas (MARTÍNEZ; MOURÃO JUNIOR; BRIENZA JUNIOR, 2010) and implies that they will make their own specific choices and engage in distinct forest restoration practices.

\section{Conclusion}

Discussions on forest restoration processes in floodplain regions, especially in Amazonian floodplains, tend to be overly simplistic given the difficulty of considering the multiplicity of factors involved. Therefore, this study sought consider the complexity of the estuarine floodplain production system, identifying possibilities and obstacles moving forward.

Forest restoration points to the return to pluriactivity, which, according to the logic of Ploeg (2008), can be seen expression of the direct control over production processes on ribeirinhos' landholdings - since açaí is no longer producers' only source of income. Additionally, in line with this author, producers' unique relationship with nature shows itself as a source of innovation, in which subjects use strategies, often described as inventions or adaptations, to improve available resources that taken together result in increased income.

Management of the floodplain ecosystem requires complex knowledge and practices. According to Almeida, Amaral and Silva (2004), given the fragility of floodplains and their low ecological resilience, removing the vegetative cover can lead to a total loss of habitat, considering that key plant species are of structural importance and responsible for maintaining this ecosystem.

Ribeirinhos understand the need and importance of maintaining natural resources in the long-term. Thus, they seek management practices that maintain açai productivity and forest resources. According to our informants, intensive management that solely prioritized açai production is short-term gain. This is a lose-lose scenario, since açai production is carried out in a way that harms the forest, causing damage on a global level and directly harming the people who directly depend on local resources.

This study showed three strategies used to restore forest areas in the Amazonian 
estuary: area enrichment, directing regeneration and cultivation of native species. Restoration processes are motivated by several factors, including environmental concerns, the need to diversify production (after a period of intensification) and to mitigate the impacts caused by eliminating other species from açai management (i.e. densifying açaí stands).

Regarding species' selection, producers enrich and manage their açaí stands with other species of commercial, culinary, medicinal, and ecological value, seeking multipleuse products that meet their basic subsistence needs and thus guarantee their autonomy. Forest restoration experiences are being consolidated in the municipality with support from the federal government, specifically credit lines aimed at forest conservation.

By inserting different species into degraded areas, ribeirinhos seek to recover the diversity lost during açaí intensification. Enrichment thus represents a way to conserve forests and species that may have otherwise gone extinct. In addition, the different strategies practiced by ribeirinhos reveals their commitment to sustainable production, especially considering the economic importance of açaí to ribeirinho families.

Enriching açaí groves with other species revitalizes the tradition of cultivating species of symbolic value, along with the associated practices and values passed down through generations. Thus, restoration processes take into consideration the economic importance of açai and ribeirinhos' empirical knowledge in the process of forest conservation.

In this way, restoring biodiversity has both material and immaterial meaning for ribeirinhos, involving economic-productive aspects and respect for and traditional coexistence with the natural environment of the floodplain forest, which was in danger of being lost due to hegemonic market influences.

Forest restoration seeks to promote a balance between the açai production and the growth of other floodplain forest species. As such, it prioritizes the sustainable production of açai and in the process generates more food and income for ribeirinho families.

Finally, we suggest that further research be conducted to obtain more detailed information on the effects of the different practices identified in this study with regard to the conservation of typical floodplain forest species and açai production. In this way, identified practices can potentially serve as examples for other communities or regions that also wish to undertake forest restoration efforts.

\section{Acknowledgments}

We thank the Fundação Amazônia de Amparo a Estudos e Pesquisa do Estado do Pará (FAPESPA) for the fellowship awarded to the first author and the riverine peoples of the Abaetetuba municipality who collaborated with our research and shared their knowledge with us. 


\section{References}

ALBUQUERQUE, U. P.; LUCENA, R. F. P.; CUNHA, L. V. F. C. C. (Org.). Métodos e técnicas na pesquisa etnobotânica. Recife: NUPEEA, 2010. 559 p.

ALMEIDA, S. S.; AMARAL, D. D.; SILVA, A. S. L. Análise florística e estrutura de florestas de várzea no estuário amazônico. Acta Amazônica. Manaus, v. 34, n. 4, p. 513-524, 2004.

ANDERSON, A. B.; GELY, A.; STRUDWICK, J.; SOBEL, G. L.; PINTO, M. C. Um sistema agroflorestal na várzea do estuário amazônico (Ilha das Onças, município de Barcarena, estado do Pará). Acta Amazônica. Manaus, v. 15, n. 1-2, p. 195-224, 1985.

ARAÚJO, C. T. D. de; NAVEGANTES-ALVES, L. de F. Do extrativismo ao cultivo intensivo do açaizeiro (Euterpe oleracea Mart.) no estuário amazônico: sistemas de manejo e suas implicações sobre a diversidade de espécies arbóreas. Revista Brasileira de Agroecologia. [S. l.], v. 10, p. 12-23, dec., 2015.

BENINI, R. et al. Manual de restauração da vegetação nativa, Alto Teles Pires, MT. Cuiabá: The Nature Conservancy, 2016. Disponível em: < https://www.nature.org/media/brasil/manual-restauracao-mt.pdf>. Acesso em: 14 jul. 2017.

BRONDÍZIO, E. S. The amazon caboclo and the açaí palm: forest farmers in the global market. New York: New York Botanical Garden Press, 2008. 403 p.

CIALDELLA, N; NAVEGANTES, L. de F. A. O ouro negro "açaî" irá beneficiar a agricultura familiar na Amazônia Oriental? Reflexões sobre mudanças recentes nas práticas de produção de açaí. In: CONGRESSO DA SOCIEDADE BRASILEIRA DE SISTEMA DE PRODUÇÃO, 10., 2014, Foz do Iguaçu. Anais [...]. Foz do Iguaçu: Sociedade Brasileira de Sistema de Produção, 2014.

FERREIRA, M. L. Manejo de açaizais. Marituba: EMATER-Pará, 2013. (técnico Manual, 9).

FRANKE, I. L.; LUNZ, A. M. P.; AMARAL, E. F. Metodologia para planejamento, implantação e monitoramento de sistemas agroflorestais: um processo participativo. Rio Branco: Embrapa Acre, 2000. 35 p. (Documentos, 49).

GARRAFIEL, D. R.; NOBRE, F. R. C.; DAIN, J. Manual da metodologia pesa: uma abordagem participativa. Rio Branco: PESAGRE, 1999. 33 p.

GOUVEIA, V. V. A natureza motivacional dos valores humanos: evidências acerca de uma nova tipologia. Estudos de Psicologia. Natal, v. 8, n. 3, p. 431-443, dec., 2003.

HIRAOKA, M. Mudanças nos padrões econômicos de uma população ribeirinha do estuário do Amazonas. In: FURTADO, L. G.; LEITÃO, W. M.; MELLO, A. F. de. (Org.). Povos das águas: realidades e perspectivas na Amazônia. Belém: MPEG, 1993. p. 133-157.

HOMMA, A. K. O.; NOGUEIRA, O. L.; MENEZES, A. J. E. de.; CARVALHO, J. E. U. de.; NICOLI, C. M. L.; MATOS, G. B. de. Açaí: novos desafios e tendências. Amazônia: Ciência $\mathbb{E}$ 
Desenvolvimento. Belém, v. 1, n. 2, p. 7-23, jan./jun., 2006.

HUXLEY, P. Classifying multipurpose trees: what are functional types? In: HUXLEY, P. Tropical agroforestry. Cambridge: BlackWell Science, 1999. p. 164-184.

INSTITUTO BRASILEIRO DE GEOGRAFIA E ESTATÍSTICA. IBGE Cidades: Abaetetuba (PA). Rio de Janeiro: IBGE, 2010. Disponível em: < https://cidades.ibge.gov.br/brasil/pa/abaetetuba/panorama >. Acesso em: 20 abr. 2018.

JARDIM, M. A. G.; VIEIRA, I. C. G. Composição florística e estrutura de uma floresta de várzea do estuário amazônico, Ilha do Combu, estado do Pará, Brasil. Boletim do Museu Paraense Emilio Goeldi. Belém, v. 17, n. 2, p. 333-354, 2001.

LIMA, M. A. R.; ANDRADE, E. R. G. Os ribeirinhos e sua relação com os saberes. Revista Educação em Questão. Natal, v. 38, n. 24, p. 58-87, ago., 2010.

LIMA. R. R.; TOURINHO, M. M. Várzeas da Amazônia Brasileira: principais características e possibilidades agropecuárias. Belém: FCAP, 1994. 20 p. (Serviço de Documentação e Informação).

LIMA. R. R.; TOURINHO, M. M.; COSTA, J. P. C. Várzeas flúvio-marinhas da Amazônia brasileira: características e possibilidades agropecuárias. Belém: FACP, 2000. 341 p.

LIRA, T. M.; CHAVES, M. P. S. R. Comunidades ribeirinhas na Amazônia: organização sociocultural e política. Interações. Campo Grande, v. 17, n. 1, p. 66-76, nov., 2015.

LOPES, M. L. B.; SANTANA, A. C. O mercado do fruto do açaizeiro (Euterpe oleracea Mart.) no estado do Pará. In: CARVALHO, D. F. (Org.). Economia da Amazônia nos anos 90. Belém: UNAMA, 2005. p. 65-84. (v. 2).

MARTÍNEZ, G. B.; MOURÃO JUNIOR, M.; BRIENZA JUNIOR, S. Seleção de ideótipos de espécies florestais de múltiplo uso em planícies fluviais do Baixo Amazonas, Pará. Acta Amazônica. Manaus, v. 40, n. 1, p. 65-74, jan., 2010.

MICHELAT, G. Sobre a utilização da entrevista não-diretiva em Sociologia. In: THIOLLENT, M. (Org.). Crítica metodológica, investigação social e enquete operária. São Paulo: Editora Polis, 1987. p. 191-211.

MONTES, C. S.; WEBER, J. C. Priorización de especies arbóreas para sistemas agroforestales en la selva baja del Perú. Agroforestería en las Américas. Turrialba, v. 4, n. 14, p. 12-17, 1997.

MORÁN, E. F. A ecologia das populações da Amazônia. Petrópolis: Vozes, 1990. 367 p.

NAIR, P. K. R. An introduction to agroforestry. Dordrecht: Kluwer Academic Publishers, 1993. $499 \mathrm{p}$.

NBL ENGENHARIA AMBIENTAL; THE NATURE CONSERVANCY. Manual de Restauração Florestal: um instrumento de apoio à adequação ambiental de propriedades rurais do Pará. 
Belém: The Nature Conservancy, 2013. 128 p.

NOGUEIRA, O. L.; FIGUEIRÊDO, F. J. C.; MÜllER, A. A. Manejo de açaizais nativos. In. NOGUEIRA, O. L.; FIGUEIRÊDO, F. J. C.; MÜlleR, A. A. (Org.). Açaí. Belém: Embrapa Amazônia Oriental, 2005. p. 55-60. (Sistemas de produção, 4). Disponível em: < https://www. infoteca.cnptia.embrapa.br/infoteca/bitstream/doc/408196/1/SISTEMAPROD4ONLINE.pdf>. Acesso em: mar. 2018.

NOGUEIRA, O. L. Sistema de produção do açaí. 2. ed. Belém: Embrapa, 2008. (Circular: Sistema de Produção 4).

PLOEG, J. D. V. der. Camponeses e impérios alimentares: lutas por autonomia e sustentabilidade na era da globalização. Porto Alegre: UFRGS, 2008. 372 p.

REIS, A. A. Estratégias de desenvolvimento local sustentável da pequena produção familiar na várzea no município de Igarapé-Miri (PA). 2008. 130 f. Dissertação (Mestrado em Desenvolvimento Sustentável do Trópico Úmido) - Universidade Federal do Pará, Belém, 2008.

REIS, A. A.; ALMEIDA, O. O cooperativismo como estratégia de desenvolvimento rural sustentável da pequena produção familiar na várzea do município de Igarapé-Miri (PA). In: LÓPEZ, J. D. G.; BARBOSA, M. J. de S. (Org.). Estrategias y acciones de desarrollo rural a través de cooperativas y emprendimientos solidarios. Alicante: Universidad de Alicante, 2012. p. 225-247.

RODRIGUES, R. R.; GANDOLFI, S.; NAVE, A. G.; ATTANASIO, C. M. Atividades de adequação e restauração florestal do LERF/ESALQ/USP. Pesq. Flor. Bras. Colombo, n. 55, p. 7-21, jul./dec., 2007.

SALOMÃO, R. P.; TEREZO, E. F. M.; JARDIM, M. A. G. (Org.). Manejo florestal nas várzeas: oportunidades e desafios. Belém: MPEG, 2007. 210 p.

SCHNEIDER, S. A abordagem territorial do desenvolvimento rural e suas articulações externas. Sociologias. Porto Alegre, ano 6, n. 11, p. 88-125, 2004.

SILVA, S. M. et al. Composição florística e fitossociologia do componente arbóreo das florestas ciliares da bacia do rio Tibagi, Paraná: 2. Várzea do rio Bitumirim, município de Ipiranga, PR. In: CONGRESSO NACIONAL SOBRE ESSÊNCIAS NATIVAS, 2., 1992, São Paulo. Anais [...]. São Paulo: Instituto Florestal, 1992. p. 192-198.

ZARIN, D. J.; PEREIRA, V. F. G.; RAFLES, H.; RABELO, F. G.; PINEDO-VASQUEZ, M.; CONGALTON, R. G. Mudança da paisagem em várzeas de maré perto da foz do rio Amazonas. Forest Ecology and Management. [S. l.], n. 154, p. 383-393, 2001. 


\section{Appendix A}

Table 1 - Relationship between species and their uses and occurrence in types of forest restoration areas, as maintained by ribeirinhos in Abaetetuba-PA, Brazil

\begin{tabular}{|c|c|c|c|c|c|c|}
\hline Scientific name & $\begin{array}{l}\text { Local name } \\
\text { cited by ribeir- } \\
\text { inhos }\end{array}$ & Uses & & & & \\
\hline $\begin{array}{l}\text { Carapa guianensis } \\
\text { Aubl. }\end{array}$ & Andirobeira & M; Cs; oil & $\mathrm{x}$ & $\mathrm{x}$ & $\mathrm{x}$ & $\mathrm{x}$ \\
\hline Cedrela fissilis Vell & Cedro branco & Cs & $\mathrm{x}$ & $\mathrm{x}$ & $\mathrm{x}$ & \\
\hline $\begin{array}{l}\text { Artocarpus altilis (Parkin- } \\
\text { son) Fosberg }\end{array}$ & Vapão & $\mathrm{F} ; \mathrm{M}$ & & $\mathrm{x}$ & $\mathrm{x}$ & \\
\hline $\begin{array}{l}\text { Vochysia maxima } \\
\text { Oucke }\end{array}$ & Quaruba & Cs & & $\mathrm{x}$ & & \\
\hline $\begin{array}{l}\text { Virola surinamensis (Rol.) } \\
\text { Warb. }\end{array}$ & Ucuubeira & Cs; Cm; S. & $\mathrm{x}$ & $\mathrm{x}$ & $\mathrm{x}$ & $\mathrm{x}$ \\
\hline Caryocar microcarpum & Piquiázeiro & Cs; A & $\mathrm{x}$ & & & \\
\hline $\begin{array}{l}\text { Callycophyllum spruce- } \\
\text { anum Benth. }\end{array}$ & Pau-mulato & Cs & $\mathrm{x}$ & $\mathrm{x}$ & $\mathrm{x}$ & $\mathrm{x}$ \\
\hline $\begin{array}{l}\text { Pouteria sagotiana (Baill) } \\
\text { Eyma }\end{array}$ & Massaranduba & Cs & $\mathrm{x}$ & & & \\
\hline Theobroma Cacao L & Cacaueiro & $\mathrm{F} ; \mathrm{Nf}$ & $\mathrm{x}$ & $\mathrm{x}$ & $\mathrm{x}$ & $\mathrm{x}$ \\
\hline $\begin{array}{l}\text { Astrocaryum mumbaca } \\
\text { Mart }\end{array}$ & Mumbaca & Cs; M, F & $\mathrm{x}$ & $\mathrm{x}$ & & \\
\hline $\begin{array}{l}\text { Astrocaryum murumuru } \\
\text { Mart }\end{array}$ & Murumuru & $\mathrm{Cm}$ & & $\mathrm{x}$ & $\mathrm{x}$ & \\
\hline Mauritia flexuosa L. & Miritizeiro & $\mathrm{F}, \mathrm{Cm}$ & $\mathrm{x}$ & $\mathrm{x}$ & $\mathrm{x}$ & $\mathrm{x}$ \\
\hline Oenocarpus bacaba Mart. & Bacababeira & $\mathrm{F} ; \mathrm{Cm}$ & $\mathrm{x}$ & $\mathrm{x}$ & $\mathrm{x}$ & \\
\hline Euterpe oleraceae Mart. & Açaizeiro & $\mathrm{F} ; \mathrm{Cm} ; \mathrm{M}$ & $\mathrm{x}$ & $\mathrm{x}$ & $\mathrm{x}$ & $\mathrm{x}$ \\
\hline Mouriri acutiflora Naud. & Camutim & Cs & & & & \\
\hline Spondias mombim L & Teperebazeiro & $\mathrm{F} ; \mathrm{M}, \mathrm{S}$ & & $\mathrm{x}$ & $\mathrm{x}$ & \\
\hline Pachira aquatica Aubl. & Mamorana & $\mathrm{F} ; \mathrm{M}$ & & $\mathrm{x}$ & & \\
\hline $\begin{array}{l}\text { Pentaclethra macroloba } \\
\text { (Willd.) Kuntze }\end{array}$ & Pracuúba & Cs & $\mathrm{x}$ & $\mathrm{x}$ & & \\
\hline Cecropia palmata Willd. & Embaúba & S & & $\mathrm{x}$ & & \\
\hline
\end{tabular}




\section{Calophyllum brasiliensis}

Cambess.

Jacareúba

Cs $\mathrm{X}$

Symphonia globulifera L

Ananin

Cs; S; Cm

$\mathrm{X}$

Hevea brasiliensis Muell.

Arg.

Seringueira $S$

$\mathrm{S} \quad \mathrm{x}$

Hura crepitans L

Assacúzeiro

Cs; M.

$\mathrm{X}$

Platymiscium ulei Harms

Macacaúba*

Cs

Pterocarpus santalinoides L.

Mututizeiro

Cs, S; H

Banara guianensis Aubl

Andorinheira

Wood; charcoal

Cuieira

F; M

Jenipapeiro

F; M

Abacateiro

F; M

Persea americana Mill.*

Abacaxizeiro

F

Ananas comosus

(L.) Merril

Malpighia glabra L.

Aceroleira

Mangifera indica L.

Mangueira

Anacardium occidentale L.

Cajueiro

F

Rollinia mucosa (Jacq.)

Baill.

Biribazeiro

F

$\mathrm{x}$

Bactris gasipaes Kunth.

Pupunheira

F; Cm

Platonia insignis Mart

Bacurizeiro

$\mathrm{F}$

Swietenia macrophylla

Mogno*

Cs

Inga edulis Mart.

Ingazeiro cipó $\mathrm{F}$

Cs; F

Benth.) Pittier

Jaranduba

F

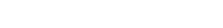

Syzygium malaccense (L.)

Merr. $\mathcal{E}$ L.M. Perry

Jambeiro

F

$\mathrm{x}$

Psidium guajava L.

Goiabeira

F

Morinda citrifolia L.

Noni

F; M

Limoeiro

F; M

Citrus limon

Cupuaçuzeiro

$\mathrm{F}$

X

Theobroma grandiflorum

Schum.

\section{Musa spp}

Cocos nucifera L

Carica papaya L.

Annona muricata L.
Bananeira F

Coqueiro

Mamoeiro

Graviola
F; Cs; M.

F; M

F; M

X

$$
\mathrm{x}
$$




\begin{tabular}{|c|c|c|c|c|c|c|}
\hline $\begin{array}{l}\text { Clitoria fairchildiana R.A } \\
\text { howard }\end{array}$ & Facãozeiro & Nf; S & $\mathrm{x}$ & $\mathrm{x}$ & $\mathrm{x}$ & $\mathrm{x}$ \\
\hline $\begin{array}{l}\text { Hieronyma laxiflora (Tul) } \\
\text { Mull. Arg }\end{array}$ & Marangosalo & Cs & $\mathrm{x}$ & & & \\
\hline Himenaea oblongifolia. & Jutaí & Cs; M & $\mathrm{x}$ & & & \\
\hline Simarouba amara Aubl & Marupá & Cs & $\mathrm{x}$ & & & \\
\hline Rhizophora mangle $\mathrm{L}$ & Siriubeira & S; & $\mathrm{x}$ & & $\mathrm{x}$ & \\
\hline Citrus SP & Toranja & $\mathrm{F} ; \mathrm{M}$ & $\mathrm{x}$ & $\mathrm{x}$ & $\mathrm{x}$ & \\
\hline Citrus sp. & Laranjeira & $\mathrm{F}$ & $\mathrm{x}$ & & & \\
\hline Raphia taedigera (Mart.) & Palheira & Cs; Cm & $\mathrm{x}$ & $\mathrm{x}$ & & $\mathrm{x}$ \\
\hline Raphia Flabelliformis & Jupati & $\mathrm{Cm} ; \mathrm{H} ; \mathrm{M}$ & $\mathrm{x}$ & $\mathrm{x}$ & & $\mathrm{x}$ \\
\hline Bixa orellana L. & Urucum & $\mathrm{F}$ & $\mathrm{x}$ & $\mathrm{x}$ & $\mathrm{x}$ & \\
\hline Lecythis pisonis Cambess & Sapucaia & $\begin{array}{l}\text { F; Cs; charcol; } \\
\text { Art }\end{array}$ & & $\mathrm{x}$ & & \\
\hline Passiflora sp & $\begin{array}{l}\text { Maracujá-do- } \\
\text {-mato }\end{array}$ & $\mathrm{F} ; \mathrm{M}$ & $\mathrm{x}$ & $\mathrm{x}$ & & \\
\hline Manicaria saccifera & Buúçu & Cs & $\mathrm{x}$ & $\mathrm{x}$ & & \\
\hline
\end{tabular}

Source: Field research, 2017.

Note:

$*(\mathrm{~F}=$ Food $),(\mathrm{H}=$ Handicrafts $),(\mathrm{Cm}=$ Commercial $),(\mathrm{Cs}=$ Construction $),(\mathrm{Nf}=$ Natural Fertilizer $),(\mathrm{M}=\mathrm{Medicinal}),(\mathrm{S}=$ Shade $)$.

\section{Appendix B}

\section{Historical interview script}

Objective: To contextualize the agrarian reality of the island region of Abaetetuba, Pará, identifying the important historical events (political, agricultural, economic, social) that have influenced forest restoration initiatives of family farmers in the region.

a. Date. b. Hour/min. of interview start and end. c. Locale. d. Interviewer. e. Interviewee. f. Institution.

g. Where is the interviewee from? f. For how long has he/she work in the region? And in the institution?

a. What was the process of land occupation in the island region? (Who was involved?) Where did they come from? What do they do?

b. Comment on the evolution of productive activities in the municipality 
over time.

c. Main events that marked local history (foundation of the municipality, road construction, projects, governments, conflicts...).

a. How would you describe the current situation in the municipality?

b. Which are the main agricultural/forest products in the region?

c. Which types of farmers can be found in the municipality (Categories, location, situation, conflicts)? Observation: Locate on map.

d. What are the main public and private institutions and organizations (unions, cooperatives, associations) that work with agriculture and, in particular, family farming? Describe their activities. Describe how they have worked in the region (date created and what they have been working on over time)?

e. $\quad$ Are there large açaí producers in the municipality? How do they operate?

f. What is the environmental situation in the municipality (especially in the floodplains)? Are there problems with deforestation, drought, erosion, strong winds?

a. What is your view on forest restoration initiatives in areas of açaí monocultures in floodplain forests?

b. What do you think motivated ribeirinhos to begin forest restoration processes in the floodplains?

c. Who are the ribeirinhos who practice forest restoration? Are there differences between them? Observation: Locate on the map.

d. Which types of initiatives are practiced (species diversification, natural regeneration)? Observation: Locate on the map.

e. Which initiatives are incentivized by institutions? What is your view on the work of institutions related to forest restoration?

f. Which development projects (Demonstrative Units, Courses) have been important to incentivizing forest restoration in the floodplains in the municipality?

g. Which financing programs (PRONAF's, Fundo Constitucional de Financiamento do Norte [FNO's]) have been made available to support forest restoration activities in floodplain forests in the municipality?

h. Do ribeirinhos have knowledge related to environmental policies? Have changes in the processes and forms of forest restoration occurred due to the implementation of environmental policies (e.g. The 2012 Forest Code in Brazil)?

i. What are the advantages afforded to and challenges faced by ribeirinhos practicing forest restoration in the municipality? 


\section{Rosileia da Costa Carvalho}

$\square$ rosileiacostacarvalho@yahoo.com.br

ORCiD: https://orcid.org/0000-0003-0177-4158
Submitted on: 20/11/2018

Accepted on: 09/02/2021

2021;24e:02693

\section{Livia de Freitas Navegantes Alves}

$\square$ lnavegantes@gmail.com

ORCiD: https://orcid.org/0000-0003-0668-8670

\section{Renan do Vale Carneiro}

$\square$ renan.vcarneiro@gmail.com

ORCiD: https://orcid.org/0000-0001-9185-800X

How to cite: CARVALHO, R. da C.; NAVEGANTES-ALVES, L. de F; CARNEIRO, R. do V. Forest restoration in the floodplains of the amazon estuary subjected to intensive açaí management. Ambiente $\&$ Sociedade. São Paulo, v. 24, p. 1-22, 2021. 


\title{
Recuperação florestal em várzeas do estuário amazônico submetidas ao manejo intensivo de açaizais
}

\author{
Rosileia da Costa Carvalho \\ Livia de Freitas Navegantes Alves \\ Renan do Vale Carneiro
}

São Paulo. Vol. 24, 2021

Artigo Original
Resumo: A expansão e o manejo intensivo dos açaizais têm provocado mudanças nas florestas de várzeas do estuário amazônico, resultando em alteração da composição florística e perda de biodiversidade, provocando problemas no ecossistema, colocando em risco a subsistência dos ribeirinhos e acarretando a necessidade de recuperação destas áreas. $\mathrm{O}$ objetivo deste trabalho foi identificar e analisar experiências de recuperação florestal realizadas nas florestas de várzeas submetidas ao manejo intensivo de açaizais no estuário amazônico, utilizando entrevista semiestruturada e formulário. Os resultados apontaram três tipos de recuperação florestal: 1) enriquecimento de área: subtipo 1- várzea alta $(7,89 \%)$ e subtipo 2 - várzea baixa $(44,75 \%) ; 2)$ condução de regeneração natural de espécies nativas $(34,21 \%) ; 3)$ plantio com espécies nativas $(13,15 \%)$. Os resultados sugerem que a recuperação florestal é capaz de promover uma produção de açaí sustentável, diversidade produtiva, renda e a conservação do ecossistema.

Palavras-chave: Agricultura; desenvolvimento sustentável; ribeirinhos; biodiversidade.

Como citar: CARVALHO, R. da C.; NAVEGANTES-ALVES, L. de F.; CARNEIRO, R. do V. Recuperação florestal em várzeas do estuário amazônico submetidas ao manejo intensivo de açaizais. Ambiente $\mathbb{\&}$ Sociedade. São Paulo, v. 24, p. 1-22, 2021. 


\title{
Recuperación forestal en llanuras de inundación del estuario amazónico sometidas a una gestión intensiva de açaizais
}

\author{
Rosileia da Costa Carvalho \\ Lívia de Freitas Navegantes Alves \\ Renan do Vale Carneiro
}

São Paulo. Vol. 24, 2021

Resumen: La expansión y el manejo intensivo de açaí han provocado

Artículo original

cambios en los bosques de várzeas del estuario amazónico, resultando en alteración de la composición florística y pérdida de biodiversidad y provocando problemas en el ecosistema, poniendo en riesgo la subsistencia de los ribereños y acarreando la necesidad de recuperación de estas áreas. El objetivo de este trabajo fue identificar y analizar experiencias de recuperación forestal realizadas en los bosques de várzeas sometidas al manejo intensivo de açaizales en el estuario amazónico, utilizando entrevista semiestructurada y formulario. Los resultados apuntaron tres tipos de recuperación forestal: 1) Enriquecimiento de área: subtipo 1várzea alta $(7,89 \%)$ y subtipo 2 - várzea baja $(44,75 \%) ; 2)$ conducción de regeneración natural de especies nativas (34,21\%); 3) plantación con especies nativas $(13,15 \%)$. Los resultados sugieren que la recuperación forestal es capaz de promover una producción de azai sostenible, diversidad productiva, renta y la conservación del ecossistema.

Palabras-clave: Agricultura; desarrollo sostenible; ribereños; biodiversidad.

Como citar: CARVALHO, R. da C.; NAVEGANTES-ALVES, L. de F; CARNEIRO, R. do V. Recuperación forestal en llanuras de inundación del estuario amazónico sometidas a una gestión intensiva de açaizais. Ambiente \& Sociedade. São Paulo, v. 24, p. 1-22, 2021.

DOI: http://dx.doi.org/10.1590/1809-4422asoc20180269r3vu2021L2AO 